http://revped.ise.ro

Print ISSN 0034-8678; Online ISSN: 2559 - 639X

\title{
THE “MIRACLE” OF EDUCATION POLICIES IN FINLAND BETWEEN EQUITY AND MUTUAL TRUST. FROM PERFORMANCE TO EXCELLENCE
}

"MIRACOLUL" POLITICILOR EDUCAȚIONALE ÎN FINLANDA ÎNTRE ECHITATE ȘI ÎNCREDERE. DE LA PERFORMANȚĂ LA EXCELENȚ̆

\section{Mihaela-Viorica RUŞITORU}

\author{
Journal of Pedagogy, 2018 (2), 93 - 102 \\ https://doi.org/10.26755/RevPed/2018.2/93
}

The online version of this article can be found at: http://revped.ise.ro/category/2018-en/

\section{(๑) $\odot \odot$}

This work is licensed under the Creative Commons Attribution-NonCommercial-ShareAlike 4.0 International License. 94042, USA

Published by:

\section{INSTITUTUL DE ȘTIINȚE ALE EDUCAȚIEI}

http://www.ise.ro/

Further information about Revista de Pedagogie - Journal of Pedagogy can be found at: Editorial Policy: http://revped.ise.ro/editorial-policy/ Author Guidelines: http://revped.ise.ro/the-writer-guide-2/ 


\title{
THE "MIRACLE” OF EDUCATION POLICIES IN FINLAND BETWEEN EQUITY AND MUTUAL TRUST. FROM PERFORMANCE TO EXCELLENCE
}

\author{
Mihaela-Viorica Ruşitoru* \\ University of Strasbourg, \\ Strasbourg, France \\ mihaela_rusitoru@yahoo.com
}

\begin{abstract}
"Miracle" (Niemi et al., 2012), "mystery", "excellence", "performance", "worldleading", etc. are some keywords used to describe the educational system in Finland. The article analyses the main cornerstones of Finnish educational policy. Several aspects are identified and decrypted, for instance: historical and cultural framework; equality and equity for lifelong learning; culture of trust at all levels; educational performance and research-based education and quality of teacher training. The present study wants to help readers to better understand the Finnish education system and to appreciate its good pedagogical practices which could be adapted to improve the education policies.
\end{abstract}

Keywords: Culture of equity and trust, education policy, Finland.

\section{Rezumat}

„Miracol” (Niemi et al., 2012), „mister”, „,excelen ă”, „performan ă”, „,ider mondial", etc. sunt cuvinte cheie utilizate astăzi pentru a descrie sistemul de educa ie din Finlanda. Articolul de fa $\breve{a}$ analizează principalele caracteristici ale politicii educa ionale finlandeze. Câteva aspecte sunt identificate şi disecate amănun it, spre exemplu: 1) contextul istoric şi cultural; 2) egalitatea şi echitatea pentru învă area de-a lungul intregii vie $i$; 3) cultura încrederii la toate nivelurile; 4) performan a educativă şi educa ia bazată pe cercetare; 5) calitatea pregătirii profesorilor. Studiul are ca obiectiv să ajute cercetătorii şi cititorii, în general, în în elegerea sistemului de educa ie din Finlanda şi în aprecierea practicilor

* Doctor in Education Sciences, University of Strasbourg, France; associate researcher at Helsinki University, Finland and at the laboratory ELLIADD, University of FrancheComté, France. 
pedagogice relevante ce pot fi adaptate pentru ameliorarea politicilor educative.

Cuvinte-cheie: Cultura echită ii şi încrederii, Finlanda, politici educa ionale.

\section{Introduction}

More than 10 years after the first "consecration" as world's leading educational system by PISA tests developed by the Organisation for Economic Cooperation and Development (OECD), Finland continues to astonish parents, teachers, researchers, policy-makers, experts and professionals in education. Having a particular story on the European continent, this country had transformed historic opportunities into innovative strategies. Most of the success on that path was made through education. But, what exactly is the success receipt of this "Finnish miracle"? This article analyses the most relevant aspects of educational policy in Finland, namely the historical and cultural framework, the culture of equity and trust, performance and research-based education and finally the quality of teacher training. At the end, the article will present some good Finnish educational practices worthy to be shared with other educators and researchers all around the world.

\section{Pillars of education policies in Finland}

Thanks to the European programme Erasmus for young entrepreneurs, I spent almost half a year in Helsinki being strongly involved in projects focused on "exporting" educational performance abroad and recently I became associate researcher at Helsinki University. In this context, I visited an average of 30 kindergartens, primary, secondary and high schools in Helsinki, Tampere and other places organised by two national start-up on education Koulu Group and Learning Scoop. This practical experience linked to reading of specialised literature and especially to papers produced by the Finnish Lifelong Learning Foundation, gave me the opportunity to better understanding Finnish educational policies. I must confess that from my arrival in Finland, I discovered plenty of pedagogical similarities between education in Finland nowadays and education in Romania during the communism. At that time, 
Romania had a very good education system but unfortunately, after the fall of communism, good things were given up. In this regard, I could identify several cornerstones of the education policy in Finland. Without being exhaustive, this personal taxonomy lists the main pillars as follows:

1) Historic and cultural framework;

2) Equality and equity for lifelong learning;

3) Culture of trust at all levels;

4) Performance and research-based education;

5) Quality of teachers training.

Thereafter, I will briefly decrypt all items listed above, in order to put in a nutshell the main pillars of education policy in nowadays' Finland.

\section{Pillars of education policies in Finland}

With two official languages - Finnish and Swedish - and two "state" religions - Lutheran and Orthodox Christians -, Finland affirms its specificity among the European countries. After almost 600 years of Swedish occupation and 100 years of Russian occupation, the country celebrates in 2017 its 100 years of independence. Member of the European Union since 1995, Finland has almost 5.5 million inhabitants and at the present hosts more and more immigrants (2\%). Available small natural resources - mainly limited to forest - are matched by a spirit of innovation and creativity. First of all, education has contributed to Finland's success. Having a high level of educational achievement and attainment, Finland is regarded as one of the most literate societies in the world. As for the Finnish education system, some characteristics may be stressed, for example, the fact that there is no selection of pupils and students, but a national curriculum which may be adapted to local needs by the educational authorities. In Finland, children with special needs are provided with an appropriate support. Joyful learning and learning by doing are the guidelines of all educational activities. Consistent and long-term oriented educational initiatives aim at developing broad literacy and willingness to continue learning at all age.

Early childhood (pre-school) education is not compulsory. The focus is made on interaction, cooperation instead of competition, joy and happiness for 
learning or activities with small groups. This "success story" (Huiala et al., 2016) inspires more and more teachers from abroad. Compulsory education is fixed up for ages of 7 to 16 years and is completed by $99 \%$ of pupils. After that, they have the choice to go on at school for a supplementary year if they want to improve their skills and knowledge or to take directly with the next step: high schools/grammar school (comparable to Gymnasium or lycée) or vocational schools. Once this secondary stage has been completed, school leaver may enter university or polytechnics schools. Transfer is possible between these different paths at any time and at all level throughout life. The figure below illustrates the structure of education system in Finland:

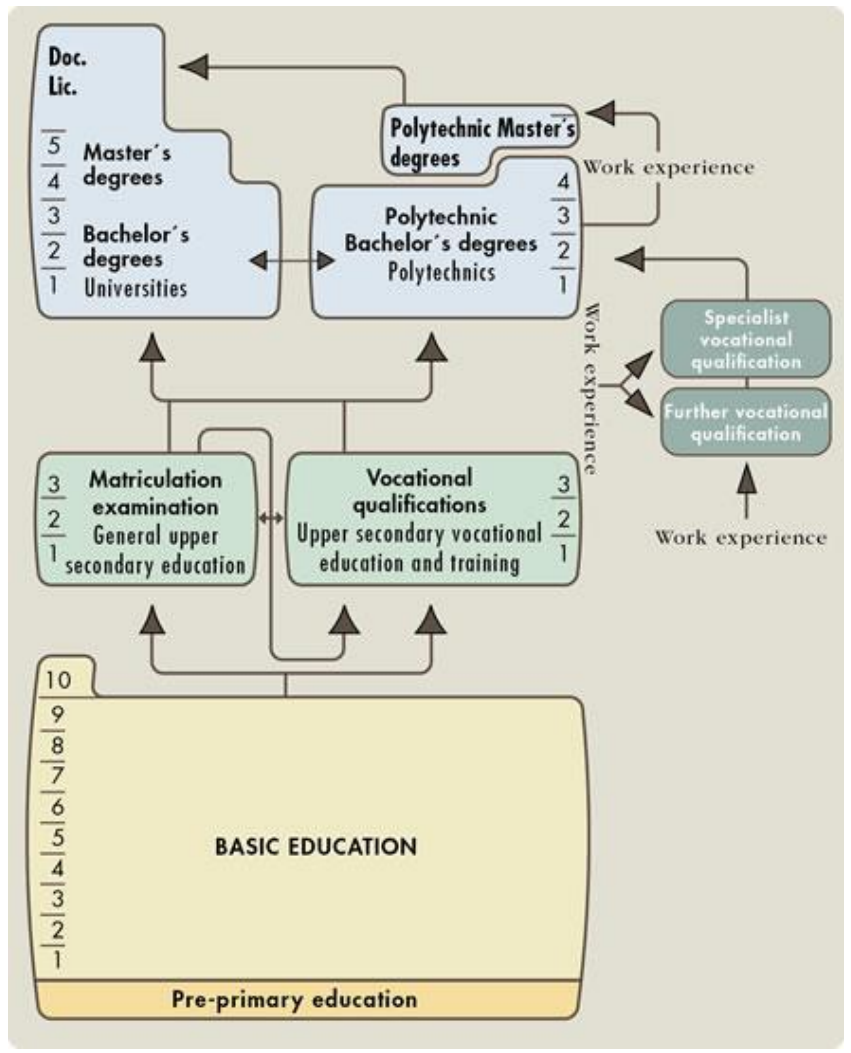

Figure no. 1. Structure of the education system in Finland Source: Internet document (see link in the References list) 
After contributing to the transformation from an agrarian country into a modern and innovation-based nation, education is today an integral part of Finnish culture and society. Currently, Finland is a trust and equity-based society where teachers are highly respected. According to international rankings, such as PISA, the country has one of the most performing education systems and the less corrupted policy-makers. Combining tradition and new technology, Finnish people borrow more books from a library than people on other countries and have the best mobile games in the world ${ }^{\mathbf{1}}$. Moreover, Finland is the best country in the world to be a mother and the most stable society with hard working people. Possessing the most saunas per inhabitant, the country is showing off with its inhabitants who are the biggest drinkers of milk and coffee.

\section{Equality and equity for lifelong learning}

In Finland, education is free of charge at all levels, including the university studies: bachelor, master and doctorate. For compulsory education this character free of charge for all includes: transport, books, meals provided at school and health care. Each learner, regardless of age, social and professional statute or any special needs, has an equal access to education everywhere and at every time. In practice, there are not selection or national tests during basic education, no streaming and no schools with special curricula in order to avoid unjustified selection of pupils. National curriculum promotes subjectivity, freedom, and flexibility (Saari, 2013). Schools are publicly founded and use the national curriculum established for pre-primary education and for basic education (Finnish National Board of Education, 2016a, 2016b). There are few private schools, mainly based on religious beliefs, alternative pedagogies or language approaches. Since these private schools follow the same national curriculum, they get also public funding. Consequently, there are no significant differences between public and private schools or between rural or urban schools.

Instead of focussing on equality, that means providing all people with the same type of knowledge and skills, Finnish educational policies are based on equity, guarantying to each learner the most appropriate thing in life situation. Education is also based on inclusion. For that reason, education for learners 
with needs for special support is most of the time conceived, organised and provided according to this education cornerstone, namely inclusion. Thus, Finland could be proud with is very well-organised special education. This particular attention paid to all person could have, in my opinion, two roots: 1) historical - because of the wars and foreign occupations, nation developed a very strongly feeling of solidarity and mutual aid - and demographical - considering the small population, confronted with a high rate of aging, the society has the moral duty to take care about all citizens. In order to face the changing society linked to the globalisation, efforts are made to integrate migrants and refugees. Language minorities are also promoted. Moreover, holistic approach of education is strongly encouraged. Finnish pupils learn how to coach, knit, work the wood, clean the house, manage money, etc. Religious, moral, sportive, musical and artistic education (Laes, 2015) is present not only for children, but also for adults.

\section{Culture of trust}

Indubitably, Finnish society is strongly rooted and based on trust at all decisional levels. We can describe this phenomenon as "cascade devolution": government trusts local authorities who trust teachers; parents trust teachers and teachers trust pupils. There is a good connection between parents and teachers who are invested with a lot of pedagogical autonomy. Trusted by the national authorities, local authorities in consultation with the teachers design the local curricula and coordinate the general assessments.

In Finland, there is no inspection or national exams in comprehensive schools. The common evaluation takes the form of sample-based monitoring and consequently, quality assurance in education mainly reposes on steering instead of regular evaluations and controlling. Teachers are rarely evaluated because both parents and decisional authorities trust them. A Finnish headmaster is, first of all, a pedagogical director and must have a teaching experience. As I mentioned, national curriculum is established at the national level by the National Board of Education who delegates administration and educational institutions to act. According to this curricular framework, teachers have autonomy to decide the: 
1) Way to emphasise their teaching;

2) Appropriate time for teaching some contents;

3) Pedagogical methods used to teach a content;

4) Subjects and topics integrated;

5) Evaluation and assessment of lessons;

6) Interdisciplinary cooperation with other teachers;

7) Where and how they teach the content.

Moreover, pupils' capacities of self-assessment are actively encouraged and supported whilst cooperation activities between them as well as the learning by teaching are strongly supported. Based on trust, teachers decide the ways of evaluation as learning and assessment.

\section{Performance and research-based education}

Finnish education is firmly impregnated by a lifelong learning approach. In this direction, the Finnish Lifelong Learning Foundation Kansanvalistusseura-, founded in 1874, testifies about this socio-educational preoccupation. Good education and training must be provided for learners of all age and in all social contexts. In the Finnish nation, education played a determinant role towards a modern society. Gifted with limited natural resources, education was and is still nowadays the most relevant "capital" for the whole society. If in the 1980's, Finnish education was scored as average among the European Union's members, but the great surprise appears at the beginning of the 2000's. Finland was placed in the first position in the world with the following scores: $1^{\text {st }}$ place in Natural Sciences and Reading and $2^{\text {nd }}$ position in Mathematics and Problem-solving. Performance and excellence become the keywords of Finnish education even if the proclaimed goal for education is not a good score on PISA tests but the training of good citizens. In this way, more than $98 \%$ of pupils attend preschool classes and $99 \%$ complete compulsory basic education. Nowadays, according to the latest PISA tests, Finland is situated on $5^{\text {th }}$ position after Singapore, Japan, Estonia, and Taiwan. In spite of that situation, the country continues to be the most efficient education systems in OECD (PISA, 2015). Concretely, that means that compared to the financial investments on education, Finland has the best results on PISA tests. 
On the other hand, education is research-based. Plenty of pedagogical experimentations are conceived by researchers and teachers who have to improve teaching methods, for example. At all level, teaching is rooted on research. Teachers have to obtain at least a master degree and their teaching activities are based on their own or their pairs' researches. Linked to that, pupils have the opportunity to experience solving problem and decision making strategies or to practice justification and argumentation. Research-based approach on education defines the Finnish principle "less is more" which notifies that education excellence is accomplished even if there are long vacations (almost 13 weeks early), there is not much homework and schooldays are relatively short.

\section{Quality of teachers' training}

For Finnish people, teaching is an attractive career choice. For men, being teacher is the best choice while for women this option arrives in third position after being doctor and veterinary surgeon. Social prestige and not good salaries - which are at the national average - motivate young people to become teachers. Teaching personnel is highly educated and respected in the society like professionals - doctors, lawyers. A master degree is required for teachers and the qualification includes preparation in special subjects as well as pedagogical studies. Thus, teachers are trained in the Department of Behaviour Sciences - psychology, educational and speech sciences, in the Department of Teacher Education - home economics, craft and educational sciences, kindergarten, special education - or in different Teachers Training Schools. Competition is tight and entrance exam comports a written exam and an interview. For teachers in primary education, there are more than 10 applicants for a place. For the secondary level, there are less candidates and the entrance exam consists only of an interview.

In primary school, teachers are generalists and teach all 13 subjects. In secondary school, they are subject specialists and teach principally a major subject and a minor one. School principals need - apart from academic degree and teacher qualification - a certificate in educational administration and work experience. Teaching training aims to empower teachers with thinking skills necessary to organise pedagogical experimentations in accordance 
with changing society and learning practices. Moreover, each year teachers participate in in-service trainings as part of lifelong learning according to personal needs and willingness.

\section{Conclusions}

To sum up, education policies in Finland are based on several cornerstones such as, trust at all level, highly educated teachers, equality and equity, cooperation and no national test, lifelong learning and holistic approach of education, student-centred pedagogy and "less is more" principle. These good practices could be spread again and again in order to help other education systems to find the better way. But, which is the specificity of Finnish educational policies? In a nutshell: "as a countervailing force against the Global Education Reform Movement that is driving schools systems around the world, the Finnish Way reveals that creative curricula, autonomous teachers, courageous leadership, and high performance go together. The Finish Way makes plain that collaboration with teachers, not confrontation, is the path to better results. The evidence is clear - and the road ahead should be, too" (Sahlberg, 2015, p. 204).

\section{Note}

1. Given that in 2017 , I was granted by the European Union to train as an expert in Finland for 6 months and in the spring of 2018, I became associate research at Helsinki University, some statistics and information provided come from conferences I attended or from electronic supports offered by trainers working in different educational startups from Finland. For that reason, "traditional references" are sometimes missing, but shortly all these information will be "officially" published by myself in a forthcoming book entitled Finnish excellence in education as I discovered it: between tradition and technologies, theory and practices; the Finnish "miracle" and pedagogical astonishment.

\section{References}

- Finnish National Board of Education. (2016a). National core curriculum for pre-primary education 2014. Tampere: Juvenes Print. 
- Finnish National Board of Education. (2016b). National core curriculum for basic education 2014. Helsinki: Finnish National Board of Education.

- Huiala, E, Valpas, A., Roos, P., \& Vlasov, J. (2016). The success story of Finnish early childhood education. Nokia: Vertikal Oy.

- Internet document. (2018). Structure of education system in Finland.

Retrieved from: https://www.google.frsearch? $q=$ Structure + of + the + education+ system + in + Finland. \& rlz $=1$ ClCHFX_frFR555FR555\&source $=$ lnms \&tbm= isch\&sa $=$ X\&ved=OahUKEwjr6YXVuOrdAhXQWsAKHdJiANEQ_AUICigB\& biw $=1346 \& b i h=591 \#$ imgrc $=Y 4 K q Z Y B o W H c Q-M$ (last accessed on September 2018).

- Laes, T. (2015). Empowering later adulthood music education: A case study of a rock band for third-age learners. International Journal of Music Education, 33(1), 51-65. https://doi.org/10.1177/0255761413515815.

- Niemi, H., Toom, A., \& Kalliiniemi, A. (2012). Miracle of education. The principles and practices of teaching and learning in Finnish schools. Rotterdam: Sense Publisher. https://doi.org/10.1007/978-94-6091-811-7.

- PISA. (2015). Excellence and equity in education. Paris: OECD.

- Sahlberg, P. (2015). Finnish Lessons 2.0. What can the world learn from educational change in Finland? New York: Teachers College Press.

- Saari, A., Salmela, S., \& Vilkkila, J. (2013). Governing autonomy. Subjectivity, freedom and knowledge in Finnish curriculum discourse, 183-200. In: Pinar, W. (2013). International handbook of curriculum research. Oxford: Taylor and Francis. https://doi.org/10.4324/9780203831694.ch14.

The online version of this article can be found at: http://revped.ise.ro/category/2018-en/

\section{(cc) $B Y-N C-B A$}

This work is licensed under the Creative Commons Attribution-NonCommercial-ShareAlike 4.0 International License.

To view a copy of this license, visithttp://creativecommons.org/licenses/by-ncsa/4.0/ or send a letter to Creative Commons, $P O$ Box 1866, Mountain View, CA 94042, USA.
Versiunea online a acestui articol poate fi găsită la:http://revped.ise.ro/category/2018-ro/

\section{(cc) BY-NC-SA}

Această lucrare este licen iată sub Creative Commons Attribution-NonCommercial-ShareAlike 4.0 International License.

Pentru a vedea o copie a acestei licen e, vizita $i$ http://creativecommons.org/licenses/by-nc-sa/4.0/ sau trimite i o scrisoare către Creative Commons, PO Box 1866, Mountain View, CA 94042, SUA. 